\title{
Halorubrum orientale sp. nov., a halophilic archaeon isolated from Lake Ejinor, Inner Mongolia, China
}

Correspondence

A. Ventosa

ventosa@us.es
A. M. Castillo, ${ }^{1}$ M. C. Gutiérrez, ${ }^{1}$ M. Kamekura, ${ }^{2}$ Y. Xue, ${ }^{3}$ Y. Ma, ${ }^{3}$
D. A. Cowan, ${ }^{4}$ B. E. Jones, ${ }^{5}$ W. D. Grant ${ }^{6}$ and A. Ventosa

${ }^{1}$ Department of Microbiology and Parasitology, Faculty of Pharmacy, University of Sevilla, 41012 Sevilla, Spain

${ }^{2}$ Noda Institute for Scientific Research, 399 Noda, Noda-shi, Chiba-ken 278-0037, Japan

${ }^{3}$ State Key Laboratory of Microbial Resources, Institute of Microbiology, Chinese Academy of Sciences, 100080 Beijing, China

${ }^{4}$ Department of Biotechnology, University of the Western Cape, Bellville 7535, Cape Town, South Africa

${ }^{5}$ Genencor International BV, Archimedesweg 30, 2333 CN Leiden, The Netherlands

${ }^{6}$ Department of Infection, Immunity and Inflammation, University of Leicester, Leicester LE1 9HN, UK

A motile, pleomorphic, red-pigmented archaeon, strain $\mathrm{EJ}-52^{\top}$, was isolated from water from Lake Ejinor, a saline lake in Inner Mongolia, China. Analysis of the almost-complete 16S rRNA gene sequence showed that the isolate was phylogenetically related to species of the genus Halorubrum, being most closely related to Halorubrum saccharovorum ATCC $29252^{\top}$ ( $96 \cdot 1 \%$ sequence similarity), Halorubrum lacusprofundi JCM $8891^{\top}$ (95.9\%), Halorubrum tibetense AS $1.3239^{\top}$ (95.2 \%), Halorubrum alcaliphilum AS $1.3528^{\top}$ (95.2\%) and Halorubrum vacuolatum JCM $9060^{\top}$ (95.1\%). The polar lipids of strain EJ $-52^{\top}$ were $\mathrm{C}_{20} \mathrm{C}_{20}$ derivatives of phosphatidylglycerol phosphate and phosphatidylglycerol phosphate methyl ester and a sulfated diglycosyl diether. Strain $\mathrm{EJ}-52^{\top}$ requires at least $2.5 \mathrm{M} \mathrm{NaCl}$ for growth and grows optimally at $3.4 \mathrm{M} \mathrm{NaCl}$. The strain grows at $25-50{ }^{\circ} \mathrm{C}$, with optimal growth occurring at $35-45^{\circ} \mathrm{C} . \mathrm{Mg}^{2+}$ is not required. The DNA G + C content is $64.2 \mathrm{~mol} \%$. On the basis of the data obtained in this study, strain EJ52 $2^{\top}$ represents a novel species, for which the name Halorubrum orientale sp. nov. is proposed. The type strain is EJ $-52^{\top}\left(=\right.$ CECT $7145^{\top}=J C M 13889^{\top}=$ CGMCC $\left.1.6295^{\top}\right)$.
Haloarchaea are aerobic members of the Archaea that are found in hypersaline habitats, mainly salt lakes and solar salterns (Rodriguez-Valera, 1988; Oren, 2000; Grant et al., 2001). They are able to grow over a wide range of salt concentrations, i.e. between 8 and $30 \% \mathrm{NaCl}$ (Grant et al., 2001). Currently, they are included in the order Halobacteriales, family Halobacteriaceae, with a large number of species being grouped in 20 genera (Grant et al., 2001; Ventosa, 2006). The genus Halorubrum was formally proposed by McGenity \& Grant (1995) to accommodate several species previously included in the genus Halobacterium: Halorubrum saccharovorum (Tomlinson \&

\footnotetext{
The GenBank/EMBL/DDBJ accession number for the $16 \mathrm{~S}$ rRNA gene sequence of strain EJ-52 ${ }^{\top}$ is AM235786.

A phase-contrast micrograph and TLC of polar lipids of strain EJ-52 ${ }^{\top}$ are available as supplementary figures in IJSEM Online.
}

Hochstein, 1976), Halorubrum sodomense (Oren, 1983), Halorubrum trapanicum (Petter, 1931) and Halorubrum lacusprofundi (Franzmann et al., 1988). In addition, Halorubrobacterium distributum (Zvyagintseva \& Tarasov, 1987) and Halorubrobacterium coriense (Kamekura \& DyallSmith, 1995) were transferred to the genus Halorubrum by Oren \& Ventosa (1996). 16S rRNA gene sequence studies showed that Natronobacterium vacuolatum (Mwatha \& Grant, 1993) was phylogenetically related to the genus Halorubrum, and it was designated Halorubrum vacuolatum (Kamekura et al., 1997). Lizama et al. (2002) described the species Halorubrum tebenquichense, isolated from Lake Tebenquiche, located in the Salar de Atacama, Chile. More recently, four novel species have been described: Halorubrum terrestre (Ventosa et al., 2004), Halorubrum tibetense (Fan et al., 2004), Halorubrum xinjiangense (Feng et al., 2004) and Halorubrum alkaliphilum (Feng et al., 2005). 
Strain EJ-52 ${ }^{\mathrm{T}}$ was isolated from water from a saline lake in Inner Mongolia, China, and was subjected to 16S rRNA gene sequence analysis, polar lipid determination and phenotypic study. The results show that strain $\mathrm{EJ}-52^{\mathrm{T}}$ is closely related to members of the genus Halorubrum.

Strain EJ-52 $2^{\mathrm{T}}$ was isolated from a sample of water from Lake Ejinor $\left(45^{\circ} 14^{\prime} \mathrm{N} 116^{\circ} 31^{\prime} \mathrm{E}\right)$ by enrichment in liquid medium and subsequent plating on the same medium with added agar until clonal purity was obtained. The medium contained the following $\left(1^{-1}\right): \mathrm{NaCl}, 195 \mathrm{~g} ; \mathrm{MgCl}_{2} \cdot 6 \mathrm{H}_{2} \mathrm{O}$, $32.5 \mathrm{~g} ; \mathrm{MgSO}_{4} .7 \mathrm{H}_{2} \mathrm{O}, 50.8 \mathrm{~g} ; \mathrm{CaCl}_{2}, 0.8 \mathrm{~g} ; \mathrm{KCl}, 5 \mathrm{~g}$; $\mathrm{NaHCO}_{3}, 0.16 \mathrm{~g} ; \mathrm{NaBr}, 0.6 \mathrm{~g}$; and yeast extract, $5 \mathrm{~g}$. The $\mathrm{pH}$ was adjusted to 8 with $1 \mathrm{M} \mathrm{NaOH}$. The water of the lake had a conductivity of $166 \mathrm{mS} \mathrm{cm}^{-1}$, a pH of 8.5 and a temperature of $32^{\circ} \mathrm{C}$ at the time of sampling in September 2003. Strain $\mathrm{EJ}-52^{\mathrm{T}}$ grew at temperatures in the range $25-50{ }^{\circ} \mathrm{C}$ (optimum, $35-45^{\circ} \mathrm{C}$ ) and at $\mathrm{pH}$ values in the range $6 \cdot 0-10 \cdot 0$ (optimum, $\mathrm{pH} 8 \cdot 0$ ). Routine cultivation was conducted at $37^{\circ} \mathrm{C}$ and $\mathrm{pH}$ 8. The $\mathrm{NaCl}$ and $\mathrm{MgCl}_{2}$ requirements for growth were determined in media containing $0 \cdot 9-5 \cdot 2 \mathrm{M} \mathrm{NaCl}$ or $0-0 \cdot 5 \mathrm{M} \mathrm{MgCl}_{2}$. Strain EJ-52 ${ }^{\mathrm{T}}$ was capable of growing in a wide range of $\mathrm{NaCl}$ concentrations, from $15 \%(2.5 \mathrm{M})$ to $30 \%(5 \mathrm{M})$; it grew optimally in the presence of $20 \%(3.4 \mathrm{M}) \mathrm{NaCl}$. The salt range and optimum for growth were found to be similar to those of most extremely halophilic archaea belonging to the Halobacteriales (Oren, 2000; Grant et al., 2001). $\mathrm{MgCl}_{2}$ was not required for growth.

Phenotypic tests were performed according to the proposed minimal standards for the description of novel taxa of the order Halobacteriales (Oren et al., 1997). Cell motility and morphology of exponentially growing liquid cultures were examined using an Olympus BX41 microscope equipped with phase-contrast optics. The cells were found to be motile and pleomorphic (see Supplementary Fig. S1 available in IJSEM Online). Colony morphology was observed under optimal growth conditions on agar medium after incubation at $37^{\circ} \mathrm{C}$ for 10 days. On agar plates, the colonies of strain $\mathrm{EJ}-52^{\mathrm{T}}$ were circular, smooth, entire and redpigmented. Anaerobic growth was tested in the presence of nitrate $\left(5 \mathrm{~g} \mathrm{l}^{-1}\right)$ or L-arginine $\left(5 \mathrm{~g} \mathrm{l}^{-1}\right)$ in filled stoppered tubes. The following characteristics were tested as described by Oren et al. (1997): hydrolysis of starch, gelatin, urea, DNA, aesculin, casein and Tween 80 ; nitrate reduction, production of indole and $\mathrm{H}_{2} \mathrm{~S}$, catalase and oxidase activities and utilization of sugars, alcohols, amino acids and organic acids as carbon and energy sources or carbon, nitrogen and energy sources. Strain EJ-52 ${ }^{\mathrm{T}}$ was found to be oxidase- and catalase-positive. Negative results were obtained for indole production from tryptophan and in methyl red, VogesProskauer and Simmons' citrate tests. Nitrate was reduced without the production of gas. Tween 80 and urea were hydrolysed, but starch, gelatin, casein, DNA and aesculin were not.

Susceptibility to antibiotics was determined on agar plates with antibiotic discs containing the following: ampicillin $(10 \mu \mathrm{g})$, bacitracin $(10 \mathrm{U})$, chloramphenicol $(30 \mu \mathrm{g})$, erythromycin $(15 \mu \mathrm{g})$, gentamicin $(10 \mu \mathrm{g})$, nalidixic acid $(30 \mu \mathrm{g})$, neomycin $(10 \mu \mathrm{g})$, novobiocin $(30 \mu \mathrm{g})$, penicillin $\mathrm{G}(10 \mathrm{U})$, rifampicin $(30 \mu \mathrm{g})$, streptomycin $(10 \mu \mathrm{g})$ and tetracycline $(30 \mu \mathrm{g})$. The results for antibiotic susceptibility and for the utilization of various substrates are included in the species description.

Polar lipids were extracted with chloroform/methanol as described previously (Kamekura, 1993). TLC was performed using Merck HPTLC plates (silica gel 60; art. no. 5641) in the solvent system chloroform/methanol/acetic acid/water $(85: 22 \cdot 5: 10: 4$, by vol.). Glycolipids were detected as purple spots by spraying $0.5 \%$ with $\alpha$-naphthol in methanol/ water $(1: 1)$ and then with sulfuric acid/ethanol $(1: 1)$, followed by heating at $160^{\circ} \mathrm{C}$. The polar lipids of strain EJ$52^{\mathrm{T}}$ (see Supplementary Fig. S2 available in IJSEM Online) are $\mathrm{C}_{20} \mathrm{C}_{20}$ derivatives of phosphatidylglycerol, phosphatidylglycerol phosphate methyl ester and the characteristic glycolipid of the neutrophilic species of Halorubrum, a sulfated mannosyl-glucosyl-glycerol diether (McGenity \& Grant, 2001).

Chromosomal DNA of strain $\mathrm{EJ}-52^{\mathrm{T}}$ was isolated and purified according to the method described by Marmur (1961). The G + C content of the genomic DNA was determined from the mid-point $\left(T_{\mathrm{m}}\right)$ of the thermal denaturation profile (Marmur \& Doty, 1962) using the equation of Owen \& Hill (1979), as described previously (Ventosa et al., 2004), and was found to be $64 \cdot 2 \mathrm{~mol} \%$. The $16 \mathrm{~S}$ rRNA gene of strain EJ-52 ${ }^{\mathrm{T}}$ was amplified by means of a PCR with three universal primers, as described previously (López-Garcia et al., 2001; Arahal et al., 1996), and an almost-complete

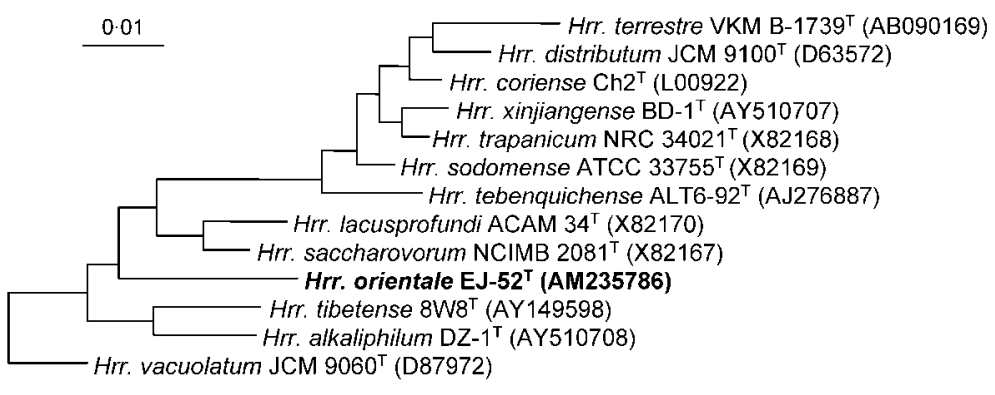

Fig. 1. Maximum-parsimony phylogenetic tree based on 16S rRNA gene sequences showing the position of strain EJ-52 ${ }^{\top}$ among the species of the genus Halorubrum. The sequence data used were obtained from the EMBL database (accession numbers are given in parentheses). Bar, $1 \%$ sequence divergence. 
Table 1. Some characteristics that distinguish strain $E J-52^{\top}$ from Halorubrum species

Strains: 1, strain EJ-52 ${ }^{\mathrm{T}} ; 2$, Hrr. saccharovorum ATCC $29252^{\mathrm{T}} ; 3$, Hrr. alkaliphilum AS $1.3528^{\mathrm{T}} ; 4$, Hrr. coriense JCM $9275^{\mathrm{T}} ; 5$, Hrr. distributum JCM $9100^{\mathrm{T}} ; 6$, Hrr. lacusprofundi JCM $881^{\mathrm{T}} ; 7$, Hrr. sodomense ATCC $33755^{\mathrm{T}}$; 8, Hrr. tebenquichense DSM $14210^{\mathrm{T}}$; 9, Hrr. terrestre VKM B-1739 ${ }^{\mathrm{T}}$; 10, Hrr. tibetense AS $1.3239^{\mathrm{T}} ; 11$, Hrr. trapanicum JCM $10477^{\mathrm{T}}$; 12 , Hrr. vacuolatum JCM $9060^{\mathrm{T}}$; 13, Hrr. xinjiangense AS $1.3527^{\mathrm{T}}$. Data were from Feng et al. (2004), Ventosa et al. (2004), Lizama et al. (2002), McGenity \& Grant (2001), Feng et al. (2005) and this study. Symbols: + , positive; - , negative; $+/-$, doubtful; ND, not done/no data available.

\begin{tabular}{|c|c|c|c|c|c|c|c|c|c|c|c|c|c|}
\hline Characteristic & 1 & 2 & 3 & 4 & 5 & 6 & 7 & 8 & 9 & 10 & 11 & 12 & 13 \\
\hline Morphology & $\begin{array}{l}\text { Pleomorphic } \\
\text { rods }\end{array}$ & Rods & $\begin{array}{l}\text { Short } \\
\text { rods }\end{array}$ & $\begin{array}{l}\text { Pleomorphic } \\
\text { short rods and } \\
\text { cup shapes }\end{array}$ & $\begin{array}{l}\text { Pleomorphic } \\
\text { rods }\end{array}$ & $\begin{array}{l}\text { Pleomorphic } \\
\text { rods }\end{array}$ & Rods & $\begin{array}{l}\text { Irregular } \\
\text { discs }\end{array}$ & Pleomorphic & Rods & $\begin{array}{l}\text { Pleomorphic } \\
\text { rods }\end{array}$ & $\begin{array}{l}\text { Pleomorphic } \\
\text { short rods }\end{array}$ & $\begin{array}{l}\text { Short } \\
\text { rods }\end{array}$ \\
\hline Cell size $(\mu \mathrm{m})$ & $1 \cdot 5-2 \times 1-2$ & $\begin{array}{c}0 \cdot 6-1 \cdot 2 \\
\times 2 \cdot 5\end{array}$ & $\begin{array}{l}0 \cdot 8-1 \cdot 0 \\
\times 1 \cdot 8-2 \cdot 0\end{array}$ & $5-0 \cdot 5$ & $0 \cdot 8-1 \times 2 \cdot 7-7$ & $>12$ & $\begin{array}{c}0 \cdot 5 \times 2 \cdot 5 \\
-5\end{array}$ & $\begin{array}{l}0 \cdot 8-1 \cdot 2 \\
\times 1 \cdot 5-1 \cdot 0\end{array}$ & $\begin{array}{l}1 \cdot 0-1 \cdot 5 \\
\times 1 \cdot 5-2 \cdot 5\end{array}$ & $\begin{array}{l}0 \cdot 5-1 \times \\
1 \cdot 5-2 \cdot 5\end{array}$ & ND & $\begin{array}{c}0 \cdot 7-10 \times \\
1 \cdot 5-3 \cdot 0\end{array}$ & $\begin{array}{c}0 \cdot 8-1 \cdot 2 \\
\times 1 \cdot 8-2 \cdot 6\end{array}$ \\
\hline Motility & + & + & + & + & + & + & + & ND & + & - & - & - & + \\
\hline Colony colour & Red & Orange-red & ND & Orange-red & Orange-red & Red & Orange-red & Red-orange & Orange-red & Red & Pale orange & Bright pink & Red \\
\hline $\begin{array}{l}\mathrm{NaCl} \text { range for } \\
\text { growth }(\mathrm{M})\end{array}$ & $2 \cdot 5-5 \cdot 0$ & $1 \cdot 5-5 \cdot 2$ & $1 \cdot 8-5 \cdot 2$ & $2 \cdot 0-5 \cdot 2$ & $1 \cdot 7-5 \cdot 2$ & $1 \cdot 5-5 \cdot 2$ & $0 \cdot 5-4 \cdot 3$ & $2 \cdot 5-5 \cdot 2$ & $2 \cdot 5-5 \cdot 2$ & $1 \cdot 7-5 \cdot 2$ & $0 \cdot 7-1 \times 1 \cdot 5-3$ & $2 \cdot 5-5 \cdot 2$ & $2 \cdot 0-5 \cdot 2$ \\
\hline pH optimum & $8 \cdot 0$ & $7-7 \cdot 5$ & $9-10$ & $7-7 \cdot 5$ & $7 \cdot 5$ & $7-7 \cdot 5$ & $7-7 \cdot 5$ & ND & $7 \cdot 5$ & $9 \cdot 0-9 \cdot 5$ & $7-7 \cdot 5$ & $9 \cdot 5$ & $7 \cdot 0-7 \cdot 5$ \\
\hline $\begin{array}{l}\text { Temperature } \\
\text { optimum }\left({ }^{\circ} \mathrm{C}\right)\end{array}$ & 37 & 50 & 38 & 50 & $37-45$ & $31-37$ & 40 & 40 & $37-45$ & $37-40$ & 37 & $35-40$ & 40 \\
\hline $\begin{array}{l}\text { Nitrate } \\
\text { reduction }\end{array}$ & + & - & + & ND & + & $+1-$ & $+1-$ & + & - & + & + & + & - \\
\hline \multicolumn{14}{|l|}{ Utilization of: } \\
\hline D-Fructose & + & + & + & ND & $\mathrm{ND}$ & - & + & + & - & ND & + & - & + \\
\hline Lactose & - & + & - & + & ND & + & + & - & ND & - & - & ND & - \\
\hline D-Galactose & - & + & - & + & - & + & - & + & ND & - & + & + & - \\
\hline Maltose & + & + & + & ND & ND & - & + & - & ND & + & + & - & + \\
\hline D-Glucose & + & + & + & + & - & + & + & + & - & + & + & + & + \\
\hline Sucrose & ND & + & - & $\mathrm{ND}$ & - & ND & + & - & ND & - & + & + & + \\
\hline $\mathrm{H}_{2} \mathrm{~S}$ production & - & + & + & ND & + & - & ND & + & - & - & ND & ND & + \\
\hline $\begin{array}{l}\text { DNA G }+ \text { C } \\
\text { content }(\mathrm{mol} \%)\end{array}$ & $64 \cdot 2$ & $71 \cdot 2$ & $62 \cdot 1$ & ND & $63 \cdot 6$ & $65 \cdot 3$ & $67 \cdot 4$ & $63 \cdot 2$ & $64 \cdot 4$ & $63 \cdot 3$ & $64 \cdot 3$ & $62 \cdot 7$ & $68 \cdot 0$ \\
\hline
\end{tabular}


nucleotide sequence (1409 bp) was determined. The ARB software package (Ludwig et al., 2004) was used for analysis of the $16 \mathrm{~S}$ rRNA gene sequence. Base-frequency filters were applied in the sequence comparison analysis and the effects on the results were evaluated. Alignment of the 16S rRNA gene sequence with all published sequences of haloarchaea clearly showed that strain $\mathrm{EJ}-52^{\mathrm{T}}$ belonged to the genus Halorubrum, since it possessed 18 of the 19 signature bases of the genus Halorubrum (Kamekura et al., 2004). The phylogenetic tree (Fig. 1) constructed by maximum parsimony (Saitou \& Nei, 1987) indicated that strain $\mathrm{EJ}-52^{\mathrm{T}}$ was related to Hrr. saccharovorum ATCC $29252^{\mathrm{T}}$ (96.1\%), Hrr. lacusprofundi JCM $8891^{\mathrm{T}}(95 \cdot 9 \%), \mathrm{Hrr}$. tibetense AS $1.3239^{\mathrm{T}}$ (95.2\%), Hrr. alcaliphilum AS $1.3528^{\mathrm{T}}(95 \cdot 2 \%)$ and Hrr. vacuolatum JCM $9060^{\mathrm{T}}(95 \cdot 1 \%)$. Similar topologies were obtained when other treeing methods (neighbour joining and maximum likelihood) were used. The low levels of similarity ( $<97 \%$ in all cases) between the 16S rRNA gene sequence of strain $\mathrm{EJ}-52^{\mathrm{T}}$ and those of the species of Halorubrum suggest that the novel isolate could represent a novel species (Stackebrandt \& Goebel, 1994; Vandamme et al., 1996). Additionally, there are phenotypic differences between strain $\mathrm{EJ}-52^{\mathrm{T}}$ and the species of Halorubrum (Table 1).

In conclusion, these data indicate that strain $\mathrm{EJ}-52^{\mathrm{T}}$ represents a novel species of the genus Halorubrum, for which we propose the name Halorubrum orientale sp. nov.

\section{Description of Halorubrum orientale sp. nov.}

Halorubrum orientale (o.ri.en.ta'le. L. neut. adj. orientale of, or belonging to, the East, eastern, pertaining to the isolation of the type strain from China).

Cells are pleomorphic, $1 \cdot 5-2 \times 1-2 \mu \mathrm{m}$ in size and motile. Colonies are small, entire, smooth and red-pigmented. Growth occurs in the presence of $2 \cdot 5-5 \cdot 0 \mathrm{M} \mathrm{NaCl}$, with optimum growth occurring at $3.4 \mathrm{M} \mathrm{NaCl} . \mathrm{MgCl}_{2}$ is not required. Growth occurs between 25 and $50{ }^{\circ} \mathrm{C}$ (optimum, $35-45^{\circ} \mathrm{C}$ ) and at $\mathrm{pH} 6 \cdot 0-10 \cdot 0$ (optimum, $\mathrm{pH} 8 \cdot 0$ ). Chemoorganotrophic. Oxidase- and catalase-positive. Nitrate is reduced to nitrite. Tween 80 and urea are hydrolysed, whereas starch, casein and gelatin are not. $\mathrm{H}_{2} \mathrm{~S}$ is not produced. Indole is not produced from tryptophan. The VogesProskauer test is negative. Arginine dihydrolase, lysine decarboxylase and ornithine decarboxylase are not produced. Anaerobic growth with nitrate or arginine does not occur. Acid is not produced from lactose, glycerol, Dglucose, sucrose, D-fructose, D-arabinose, maltose, D-xylose, D-galactose, D-trehalose and D-mannose. Growth occurs on glycerol, D-fructose, maltose, D-glucose, starch, L-glutamate and fumarate as single carbon and energy sources. The following compounds are not used as sole carbon and energy sources: D-mannitol, D-sorbitol, lactose, D-arabinose, Draffinose, D-ribose, D-xylose, succinate, propionate, malate and acetate. The following compounds are used as sole carbon, nitrogen or energy sources: L-asparagine, glycine, Llysine, L-serine and L-threonine. Susceptible to novobiocin, bacitracin, gentamicin, ampicillin, neomycin, erythromycin, chloramphenicol, nalidixic acid and streptomycin; resistant to penicillin $\mathrm{G}$ and rifampicin. The polar lipids are $\mathrm{C}_{20} \mathrm{C}_{20}$ derivatives of phosphatidylglycerol, phosphatidylglycerol phosphate methyl ester and a sulfated mannosylglucosyl-glycerol diether. The DNA $\mathrm{G}+\mathrm{C}$ content is $64 \cdot 2 \mathrm{~mol} \%$ ( $T_{\mathrm{m}}$ method).

The type strain, EJ $-52^{\mathrm{T}}\left(=\mathrm{CECT} 7145^{\mathrm{T}}=\mathrm{JCM} 13889^{\mathrm{T}}=\right.$ CGMCC $1.6295^{\mathrm{T}}$ ), was isolated from Lake Ejinor, a saline lake in Inner Mongolia, China.

\section{Acknowledgements}

This study was supported by grants from the Quality of Life and Management of Living Resources Programme of the European Commission (Project 'Multigenome Access Technology for Industrial Catalysts', QLK3-CT-2002-01972), the Spanish Ministerio de Educación y Ciencia (BMC2003-01344) and the Junta de Andalucia.

\section{References}

Arahal, D. R., Dewhirst, F. E., Paster, B. J., Volcani, B. E. \& Ventosa, A. (1996). Phylogenetic analyses of some extremely halophilic archaea isolated from Dead Sea water, determined on the basis of their 16S rRNA sequences. Appl Environ Microbiol 62, 3779-3786.

Fan, H., Xue, Y., Ma, Y., Ventosa, A. \& Grant, W. D. (2004). Halorubrum tibetense sp. nov., a novel haloalkaliphilic archaeon from Lake Zabuye in Tibet, China. Int J Syst Evol Microbiol 54, 1213-1216.

Feng, J., Zhou, P. \& Liu, S. (2004). Halorubrum xinjiangense sp. nov., a novel halophile isolated from saline lakes in China. Int J Syst Evol Microbiol 54, 1789-1791.

Feng, J., Zhou, P., Zhou, Y., Liu, S. \& Warren-Rhodes, K. (2005). Halorubrum alkaliphilum sp. nov., a novel haloalkaliphile isolated from a soda lake in Xinjiang, China. Int J Syst Evol Microbiol 55, 149-152.

Franzmann, P. D., Stackebrandt, E., Sanderson, K., Volkman, J. K., Cameron, D. E., Stevenson, P. L., McMeekin, T. A. \& Burton, H. R. (1988). Halobacterium lacusprofundi sp. nov., a halophilic bacterium isolated from Deep Lake, Antarctica. Syst Appl Microbiol 11, 20-27.

Grant, W. D., Kamekura, M., McGenity, T. J. \& Ventosa, A. (2001). Order I. Halobacteriales Grant and Larsen 1989b, 495 ${ }^{\mathrm{VP}}$ (Effective publication: Grant and Larsen 1989a, 2216). In Bergey's Manual of Systematic Bacteriology, 2nd edn, vol. 1, pp. 294-299. Edited by D. R. Boone, R. W. Castenholz \& G. M. Garrity. New York: Springer.

Kamekura, M. (1993). Lipids of extreme halophiles. In The Biology of Halophilic Bacteria, pp. 135-161. Edited by R. H. Vreeland \& L. I. Hochstein. Boca Raton, FL: CRC Press.

Kamekura, M. \& Dyall-Smith, M. L. (1995). Taxonomy of the family Halobacteriaceae and the description of two genera Halorubrobacterium and Natrialba. J Gen Appl Microbiol 41, 333-350.

Kamekura, M., Dyall-Smith, M. L., Upasani, V., Ventosa, A. \& Kates, M. (1997). Diversity of alkaliphilic halobacteria: proposals for transfer of Natronobacterium vacuolatum, Natronobacterium magadii, and Natronobacterium pharaonis to Halorubrum, Natrialba and Natronomonas gen. nov., respectively, as Halorubrum vacuolatum comb. nov., Natrialba magadii comb. nov., and Natronomonas pharaonis comb. nov., respectively. Int J Syst Bacteriol 49, 131-136. Kamekura, M., Mizuki, T., Usami, R., Yoshida, Y., Horikoshi, K. \& Vreeland, R. H. (2004). The potential use of signature bases from $16 \mathrm{~S}$ 
rRNA gene sequences to aid the assignment of microbial strains to genera of halobacteria. In Halophilic Microorganisms, pp. 77-87. Edited by A. Ventosa. Heidelberg: Springer.

Lizama, C., Monteoliva-Sánchez, M., Suárez-Garcia, A., RossellóMora, R., Aguilera, M., Campos, V. \& Ramos-Cormenzana, A. (2002). Halorubrum tebenquichense sp. nov., a novel halophilic archaeon isolated from the Atacama Saltern, Chile. Int J Syst Evol Microbiol 52, 149-155.

López-Garcia, P., Moreira, D., López-López, A. \& Rodríguez-Valera, F. (2001). A novel haloarchaeal-related lineage is widely distributed in deep oceanic regions. Environ Microbiol 3, 72-78.

Ludwig, W., Strunk, O., Westram, R. \& 29 other authors (2004). ARB: a software environment for sequence data. Nucleic Acids Res 32, 1363-1371.

Marmur, J. (1961). A procedure for the isolation of deoxyribonucleic acid from micro-organisms. J Mol Biol 3, 208-218.

Marmur, J. \& Doty, P. (1962). Determination of the base composition of deoxyribonucleic acid from its thermal denaturation temperature. J Mol Biol 5, 109-118.

McGenity, T. J. \& Grant, W. D. (1995). Transfer of Halobacterium saccharovorum, Halobacterium sodomense, Halobacterium trapanicum NRC 34021 and Halobacterium lacusprofundi to the genus Halorubrum gen. nov., as Halorubrum saccharovorum comb. nov., Halorubrum sodomense comb. nov., Halorubrum trapanicum comb. nov., and Halorubrum lacusprofundi comb. nov. Syst Appl Microbiol 18, 237-243.

McGenity, T. J. \& Grant, W. D. (2001). Genus VII. Halorubrum McGenity and Grant 1996, 362 ${ }^{\mathrm{VP}}$ (Effective publication: McGenity and Grant 1995, 341). In Bergey's Manual of Systematic Bacteriology, 2nd edn, vol. 1, pp. 320-324. Edited by D. R. Boone, R. W. Castenholz \& G. M. Garrity. New York: Springer.

Mwatha, W. E. \& Grant, W. D. (1993). Natronobacterium vacuolata sp. nov., a haloalkaliphilic archaeon isolated from Lake Magadi, Kenya. Int J Syst Bacteriol 43, 401-404.

Oren, A. (1983). Halorubrum sodomense sp. nov., a Dead Sea halobacterium with an extremely high magnesium requirement. Int $J$ Syst Bacteriol 47, 233-238.

Oren, A. (2000). The order Halobacteriales. In The Prokaryotes. An Evolving Electronic Resource for the Microbiological Community, release 3.2. Edited by M. Dworkin, S. Falkow, E. Rosenberg, K. H. Schleifer \& E. Stackebrandt. New York: Springer. http://141.150.157. 117:8080/prokPUB/index.htm
Oren, A. \& Ventosa, A. (1996). A proposal for the transfer of Halorubrobacterium distributum and Halorubrobacterium coriense to the genus Halorubrum as Halorubrum distributum comb. nov. and Halorubrum coriense comb. nov., respectively. Int J Syst Bacteriol 46, 1180.

Oren, A., Ventosa, A. \& Grant, W. D. (1997). Proposed minimal standards for description of new taxa in the order Halobacteriales. Int J Syst Bacteriol 47, 233-238.

Owen, R. J. \& Hill, L. R. (1979). The estimation of base compositions, base pairing and genome size of bacterial deoxyribonucleic acids. In Identification Methods for Microbiologists, 2nd edn, pp. 217-296. Edited by F. A. Skinner \& D. W. Lovelock. London: Academic Press.

Petter, H. F. M. (1931). On bacteria of salted fish. Proc K Ned Akad Wet Amsterdam 34, 1417-1423.

Rodriguez-Valera, F. (1988). Characteristics and microbial ecology of hypersaline environments. In Halophilic Bacteria, vol. 1, pp. 3-31. Edited by F. Rodriguez-Valera. Boca Raton, FL: CRC Press.

Saitou, N. \& Nei, M. (1987). The neighbor-joining method: a new method for reconstructing phylogenetic trees. Mol Biol Evol 4, 406-425.

Stackebrandt, E. \& Goebel, B. M. (1994). Taxonomic note: a place for DNA-DNA reassociation and 16S rRNA sequence analysis in the present species definition in bacteriology. Int J Syst Bacteriol 44, 846-849.

Tomlinson, G. A. \& Hochstein, L. I. (1976). Halobacterium saccharovorum sp. nov., a carbohydrate-metabolizing, extremely halophilic bacterium. Can J Microbiol 22, 587-591.

Vandamme, P., Pot, B., Gillis, M., De Vos, P., Kersters, K. \& Swings, J. (1996). Polyphasic taxonomy, a consensus approach to bacterial classification. Microbiol Rev 60, 407-438.

Ventosa, A. (2006). Unusual micro-organisms from unusual habitats: hypersaline environments. In Prokaryotic Diversity: Mechanisms and Significance (Society for General Microbiology Symposium no. 66), pp. 223-253. Edited by N. A. Logan, H. M. Lappin-Scott \& P. C. F. Oyston. Cambridge: Cambridge University Press.

Ventosa, A., Gutiérrez, M. C., Kamekura, M., Zvyagintseva, I. S. \& Oren, A. (2004). Taxonomic study of Halorubrum distributum and proposal of Halorubrum terrestre sp. nov. Int J Syst Evol Microbiol 54, 389-392.

Zvyagintseva, I. S. \& Tarasov, A. L. (1987). Extreme halophilic bacteria from saline soils. Microbiology (English translation of Mikrobiologiia) 56, 839-844. 